\title{
Species Richness And Diversity of Sea Birds And Shore Birds of Red Sea Region In Massawa, Eritrea, North East Africa
}

\author{
Yohana Tekle ${ }^{1}$ And Kunduru Surender Reddy ${ }^{2}$ \\ ${ }^{1}$ \& 2 Department Of Biology, Eritrea Institute Of Technology, \\ Mai Nefhi, Asmara, Eritrea, North East Africa
}

\begin{abstract}
Large number of birds are found in Red Sea region since there was no potential predators found in that region and hence the birds were selected it as a feeding and breeding ground for the sea and shore birds. The research site was around 0.05 sq.kms and it constitute about 50\% of the island with mangrove cover and this also added for it for a nestling of their off-springs. The island with rich of Avicenna marina as a mangrove forests will cover most for shelter and breeding to these birds either migratory or resident birds and will act as symbiotic relationship with the birds. And from November to February during the survey 27 of sea and 11 of the shore birds were recorded. Shannon Wiener's index and Simpson's index for calculating the Diversity and Species Richness were used to represent the data. As per the results and the calculated data the richness and the diversity of the area of the birds were less than 1 and hence less diversity and abundance of the species.
\end{abstract}

Keywords: Sheik Said Island, Salicornia, Sacred Ibis, Whimbrel, Red sea region, Massawa,

\section{Introduction}

Birds are bipedal, warm-blooded, oviparous vertebrate animals characterized primarily by feathers, forelimbs modified as wings, and hollow bones. Birds range in size from the tiny hummingbirds to the huge Ostrich and Emu. Depending on taxonomic viewpoint, there are about 8,800-10,200 living bird species (plus about 120-130 that have become extinct in the span of human history) in the world, making them the most diverse class of terrestrial vertebrates. Birds feed on nectar, plants, seeds, insects, rodents, fish, carrion, or other birds. Most birds are diurnal, or active during the day. Some birds, such as the owls and nightjars, are nocturnal or crepuscular (active during twilight hours) and some are shorebirds where there is a sea shore and is a rich resources for food, breeding and nesting behavior for its future off-spring. Birds are among the most extensively studied of all animal groups. Hundreds of academic journals and thousands of scientists are devoted to bird research, while amateur enthusiasts (called birdwatchers or, more commonly, birders) probably number in the millions because of its unique features.

The Directory of IBAs in Eritrea identifies 14 sites as IBAs in the country. Eritrea's IBAs comprise wide range of habitats critical for birds, including: wetlands, high altitude mountains, desert wades, coastal plains and marine islands of Massawa, Red Sea Region, North East Africa, Eritrea. Five of Eritrea's IBAs are in existing Protected Areas and have been identified and anther ten further IBAs have been proposed for protection and conservation. However, not all IBAs can become Protected Areas .Bird conservation needs at sites such as green island and Dahalak Island of this region.

The Eritrean coasts and islands are well known for the large diversity of birds particularly sea and shorebirds. These two groups are specialized on feeding on the abundant food resources to be found in and close to the sea and are usually confined to the inter-tidal zone of Red Sea region. Many species of seabirds and shorebirds migrate very long distances, the most common pattern being for birds to breed in the temperate or arctic northern hemisphere and winter in the warmer regions, often in the tropics or the southern hemisphere.

The Red Sea is one of the richest areas in the world. The Red Sea is the world's last great unspoiled tropical paradise and features a range of important coastal habitats. The Eritrean Red Sea coast is represented as a southern part of the Red Sea, with a coastline extending over 1350 kilometers and 1995 island coast (ECMIB Project MoF, 2006). There are very large numbers of birds on the shores and respectively on the shallow water of the Eritrean Red Sea. Birds appear to be concentrated in large number on the exposed intertidal of varying size and on the shallow and open sea. The most characteristic feature of this habitat type are the large number of invertebrates that become visible during low tides, the small fishes in the shallow water and the shoal of large and small fishes and planktons on the open sea. These rich sources of food which is dead coral deposit on the varying habitats of the Eritrean Red Sea attract large number of birds, such as waders, herons, gulls, terns, boobies and other species.

The large number of islands on the Eritrean waters provides critical habitat for a large number of seabirds' colony on summer. The open sand above the intertidal zone is suitable breeding site for terns and other birds such as the lesser-crested, white-cheeked and the crab plover. The various vegetation type provide excellent breeding habitat for bridled terns, sooty gull, herons and pelicans. The coral cliff and coral out crop is 
suitable nesting site for sooty falcon and green backed heron. Some of the important breeding population includes the White-eyed Gull Larus leucophthalmus, the Crab Plover Dromas ardeola, Brown Noddy Anous stolidus, White-cheeked Tern Sterna repressa and Sooty Falcon Falco concolor.

The status of breeding seabirds on the Eritrean islands was poorly known until 2005. Because of the long-running war, recent ornithological records for Eritrea are limited and large areas of the country have never been surveyed. In addition, many of the older records do not differentiate between Ethiopia and Eritrea. The great colonies of breeding seabirds in summer' were first recorded by Heuglin in the nineteenth century (Heuglin, 1858). Since then some ornithological studies carried in the mid $20^{\text {th }}$ century by some ornithologists such as Salvadori 1954, Smith 1955, 1957, Clapham 1964, and Torneille 1964. The islands have not been visited since then due to a long period of war between Eritrea and Ethiopia that restrict any survey work by nationals or expatriate scientists (MOF, 1997). Some observations have been made on some islands and the coasts from 1991- 1998 by the Ministry of Fisheries (Chris Hillman) and GEF Pre Investment Fund. However those studies contribute very little information on breeding seabirds and shorebirds. In 1998 a project set up called ECMIB (Eritrean Coastal Marine and Island Biodiversity Project) funded by GEF (Global Environmental Facility) to study the biodiversity of Eritrean Red Sea. One important aspect of the Project was access given to determine the current status of breeding seabirds and their habitat. As a result intensive survey conducted by seabird expert of the Project, which covered more than $80 \%$ of the islands within two years (2005-2006).

\section{The objectives of this study were:}

\section{Objective Of The Study}

1. Estimate bird species, population size, and their distribution in the area considering deposit of dead coral

2. Study the breeding season of bird species

3. Identification and naming of halophytes plants and their role to the breeding and non breeding birds

4. Determine resident and migrant birds and their abundance during the survey

5. To identify if any other factors like high tide, low tide humidity affect abundance of birds

\section{Study Areas}

The study was conducted in island called Green Island also known as Sheik Said Island it is located 1$1.5 \mathrm{~km}$ to the south of nearest land Massawa and represent a unique site to study the extent of trans-gulf migration in many avian taxa. It is a small island estimated to be $11 \mathrm{ha}$. It is characterized by a dense mangrove forest, which makes it evergreen and more attracted by birds. Most of the area above the high tide level is covered by salt tolerant short plant vegetation such as salicornia. Intertidal area is very vast which comprises, rocky, sandy and muddy substrates. The entire island is suitable for marine birds to feed, to roost on the sandy beach and mangrove forest.(identification of sea birds in green is land by Yossief and Sammy Yohannes 2006) The diversity and abundance of birds differs from area to area depending on the richness of the area, the habitat structure and the weather condition. The highest species diversity and abundance in Sheik Said Island can be associated with the large area that exposes at low tide which is rocky, muddy and sandy, rich in invertebrates specially crabs. This attracts many species of waders. The dense mangrove forest is a home for juvenile fishes, invertebrates and it is a resting and residing place for some species of herons, pelican, spoonbill and sacred ibis and other wader feeding and roosting on top of it. The water below the intertidal is a source of fishes where pelicans, terns feed on. In addition the sandy beach is an excellent roosting site for several waders and sea birds. Mangrove forests are best developed on tropical shorelines where there are large areas available between high and low tide points. Large mangrove formation is typically found in sheltered muddy shorelines that are often associated with the formation of deltas at the mouth of a river system. Mangroves can also be found growing on sandy and rocky shores, coral reefs and oceanic islands. There are instances where islands can be completely covered by mangroves. It is impossible to describe a typical mangrove forest, as the variation in height and girth, even for the same species, is immense, depending on the many factors that control growth

All plants require various mineral elements to survive and these are absorbed by the roots from the soil. Plants require nitrogen, phosphorus, potassium, calcium, magnesium, sulphur and iron. Sodium chlorides required only in trace quantities and this poses certain problems for mangroves due to high abundance of these two elements in the sea water surrounding their roots. Other trace elements required by the plants for successful growth are boron, manganese, zinc, copper and molybdenum.

Mangrove soils are quite different from those that most other terrestrial plants grow on. They are poorly drained, lacking in oxygen and are often fine grained and rich in organic matter. In appearance the soils are often clayey mud or sand.

Mangroves grow on waterlogged soils that are often lacking in oxygen. These are known as anaerobic soils, literally, soil without air. The lack of oxygen in the soil is due to the slow rate of diffusion of oxygen in water and the biological activity of microorganisms in the soil which consumes oxygen. The amount of oxygen in the soil varies according to how often and for how long tides cover the mud, how well drained the areas are, 
and whether there are chemicals in the soil that absorb oxygen. Oxygen in the soil could be expected to increase in proportion to the amount of time that the soil is exposed to the air and the soil is covered by water. Extreme lack of oxygen in the soil can lead to the formation of gas, hydrogen sulphide, which has rotten egg smell often associated with mangrove swamps. Some of the mangroves found in Red Sea region of the islands are Rhizophora mangle or the red mangrove, Avicenna; coastal fringes form a good breeding environment.

The mangrove animals live in a variety of habitats which can range from within or on the surface of the mud, through the creeks, channels and pools, to the tree roots, trunk and canopy. The tidal cycle exercises a profound influence over the behavior and activity of marine animals in the mangrove. Large mangrove animals living on the surface of the mud, which is exposed at low tides, are almost always protected from drying out by a shell or some hard supporting structure. In Sheik Seid Island, the mangrove area is distributed over 0.05 sq.km. It constitutes $50 \%$ of the Island. Only Avicennia marina dominated the mangrove forest. The eastern party of the forest, with muddy substratum is denser and larger in height than the western with sandy substratum. These can truth that mangroves prefer muddy substratum to sandy substratum. The mangrove of Sheik Seid Island supports many species of birds including migratory and resident. These birds use the mangrove as a shelter. Apart from this, the Sheik Seid Island mangroves provide a critical habitat for many marine organisms including gastropods (e.g. Littorina scabra found commonly attached to the pneumatophores), crustaceans (e.g. hermit crabs, Uca spp., and black colour crabs (unidentified) with borrowing in between the pneumatophores, rats (Fig.23) and others. Halophytes including Zygophylum spp, wild salicornia, and Seueda spp are covering large area of the Island.

In Sheik Seid Island the distribution and abundance of key indicators species of the three types of substratum (rocky, sandy and muddy) was recorded. Greater distribution and abundance of the key indicators species was observed on the rocky shore compared to the other shores. Generally, there was greater distribution and abundance of flora and fauna in the eastern (sea ward) of the island. This could be due to the pollutants released from the city and port activities of Massawa or other unique features. Depending on the habitat structure and size of the island it is difficult to record all birds staying in one vantage point. We select mainly two vantage points. One we climbed on top of the large mangrove trees to count the pink backed pelicans, spoonbill, sacred ibis and western reef heron that were on top of the mangrove forest and to those bird that were on the sand beach toward the side facing to Tuwalot Island. The second vantage point was on the seaward side facing toward Hirgigo where there is a dead coral deposit. This site covers most of the intertidal area of the Island toward the open sea. In addition we walked all the way along the mangroves to check for unrecorded birds. We counted directly bird's weather they were feeding, roosting, resting and flying overhead.

\section{Material and Methods}

The material that were used to conduct the study were boat for transport from Massawa, Red sea Region, to the area of our study green island and set of binocular, note book, a satellite based map and GPS systems of green island and Stunderd Feield Guide Book Birds of Africa south of Sahara (Peter Rayan) also some data analyses formulas to complete the studies.

The field study was run during four month from November 2013 to February 2014 each visit was given more than two hours except for the first visit since it was high tide this is to study the richness of the area and abundance of the bird . on each visit all the birds were counted except for the unidentified birds we didn't consider them in recording data .the field study were run during different times early morning and late afternoon because some birds that we couldn't observe in the morning could be found in the after noon

\section{Results and the observation}

Birds were censured 3 times at different season during different weather conditions. A boat was used to gain access to the island during crossing of the open sea we tried to maintain and capture some pictures of the island and the birds. The island is A-sized Island, which takes two to four hours on land for rapid assessment we reached all areas on foot also the mangrove stands or dense shrubbery has been checked. We tailed the number of birds of all species observed by researcher each survey. In total we documented almost 30 species of birds in the study area comprises of more than 500 individuals. Our most abundant observation include $(>100$ observation over season): pink backed pelican, sooty gull, and common sand piper, and our most common observation (>20 individual observation) is sacred ibis, osprey, and house crow. And our most uncommon observation is $(<5$ observation).

November 302013 we under took the first study of our research for both shore birds and sea birds in green island over the course of our field season during high ppt, sunny weather were the state of tide was from high to low. At the beginning of the census some birds where counted while their roasting on their nest due to high tide the population density was low .crab plover was high in number since they are resident. we located few nests since it was high tide all the mangrove areas were under water and we also done environmental monitoring activities from 1.30 to 2.30 by taking the island as A sized island at the end of the survey we come to conclude 
that 8 of the species were sea birds and the 3 were shore birds including black belled plover, pink backed pelican, osprey, sacred ibis and other birds as listed in the tabular form. But crab plover was found to be more in number this birds are the only birds found to breed in colonies, nesting only occurs in northwestern Indian and red sea which also include green island. These birds are discovered to breed underground and has been studied by von Heuglin who recorded this behavior while visiting the Dahalak island in 1857 and 1861 (von Henglin 1861) surprisingly this breeding record was lost and later ornithologist found no evidence of breeding on Dahlak where breeding was only suspected (Smith 1957, Chris, 2006, Urban and Bosswell 1969).

\section{Calculation Of The Data}

The data were calculated by using Shannon Weiner's Index for Habitat Diversity Index and Simpson's index (1949) for species diversity and if the values were more than 1 then the species in that area were abundance. The calculated values may range from 0 to 5 and the least values is at 0 and the maximum values at 5 for both richness or abundance and diversity for both the principles.

Shannon Weiner's Index:

$$
H=-\sum_{i=1}^{5}\left[p_{i} \times \ln p_{i}\right]
$$

Simpson's index:

$$
\operatorname{Sim}=\frac{2 \sum n c}{\sum n 1+\sum n 2}
$$

Where $\mathrm{p}_{\mathrm{i}}=$ the relative abundance of the species, $\mathrm{n}_{\mathrm{i}}$ the abundance of the species, $\mathrm{nc}$ is the common species between the sites, $\mathrm{H}$ is the diversity index, $\mathrm{s}$ is number of species in the sample, Sim is Simpsons index, $\mathrm{N}$ is the total number of individuals among s species and if the $\mathrm{p}_{\mathrm{i}}$ calculated values are more than 1 then the species richness and abundance is more in that area. 
Species Richness And Diversity Of Sea Birds And Shore Birds Of Red Sea Region In Massawa...

\begin{tabular}{|c|c|c|c|c|c|c|c|}
\hline \multicolumn{8}{|c|}{ Observed Species Identification List: A: Sea Birds } \\
\hline S. No & Common Name & Scientific Name & $\begin{array}{l}\text { Migrant / } \\
\text { Resident }\end{array}$ & $\begin{array}{c}\text { Abundance } \\
\mathbf{n}_{\mathbf{i}}\end{array}$ & $\mathrm{p}_{\mathrm{i}}$ & $\ln$ & $\ln \mathrm{pi}$ \\
\hline 1. & $\begin{array}{ll}\text { Pink } & \text { Backed } \\
\text { Pelican } & \\
\end{array}$ & Pelianus ruescens & Resident & 59 & 2.36 & -4.5696 & 0.8587 \\
\hline 2. & $\begin{array}{l}\text { Lesser Black- } \\
\text { backed gull }\end{array}$ & Larus fuscus & Resident & 4 & 0.16 & .9744 & 1.8326 \\
\hline 3. & Sooty gull & Larus hemprichii & Resident & 31 & 1.24 & -0.5376 & 0.2151 \\
\hline 4. & Caspian Tern & Sterna caspia & Resident & 2 & 0.08 & 0.9936 & 2.5257 \\
\hline 5. & Osprey & Pandion haliaetus & Resident & 5 & 0.2 & 0.96 & 1.6094 \\
\hline 6. & $\begin{array}{l}\text { Eurasian } \\
\text { spoonbill }\end{array}$ & Platalea leucorodi & Resident & 7 & 0.28 & 0.9216 & 1.2730 \\
\hline 7. & Sacred Ibis & $\begin{array}{l}\text { Threskiornis } \\
\text { aethiopicus }\end{array}$ & Resident & 94 & 3.76 & $\begin{array}{c}- \\
13.137 \\
6\end{array}$ & 1.3244 \\
\hline 8. & $\begin{array}{l}\text { Western-reef } \\
\text { Heron }\end{array}$ & Egretta gularis & Resident & 5 & 0.2 & 0.96 & 1.6094 \\
\hline 9. & $\begin{array}{l}\text { Greater } \\
\text { Flamingo }\end{array}$ & $\begin{array}{l}\text { Phoenicopterus ruber } \\
\text { raseus }\end{array}$ & Migrant & 1 & 0.04 & 0.9984 & 3.2189 \\
\hline 10. & Brown booby & sula leucogaster & Resident & 4 & 0.16 & 0.9744 & 1.8326 \\
\hline 11. & Slender bill gull & Larus genei & Resident & 11 & 0.44 & 0.8064 & 0.8210 \\
\hline 12. & $\begin{array}{l}\text { Lesser crested } \\
\text { tern }\end{array}$ & Sterna bengalensis & Resident & 21 & 0.84 & 0.2944 & 0.1744 \\
\hline 13. & Common tern & Sterna hirundu & Resident & 2 & 0.08 & 0.9936 & 2.5297 \\
\hline 14. & Brown noddy & Anous stolidus & Resident & 4 & 0.16 & 0.9744 & 1.8326 \\
\hline 15. & Gery heron & Areda cinerea & Resident & 3 & 0.12 & 0.9856 & 2.1203 \\
\hline
\end{tabular}

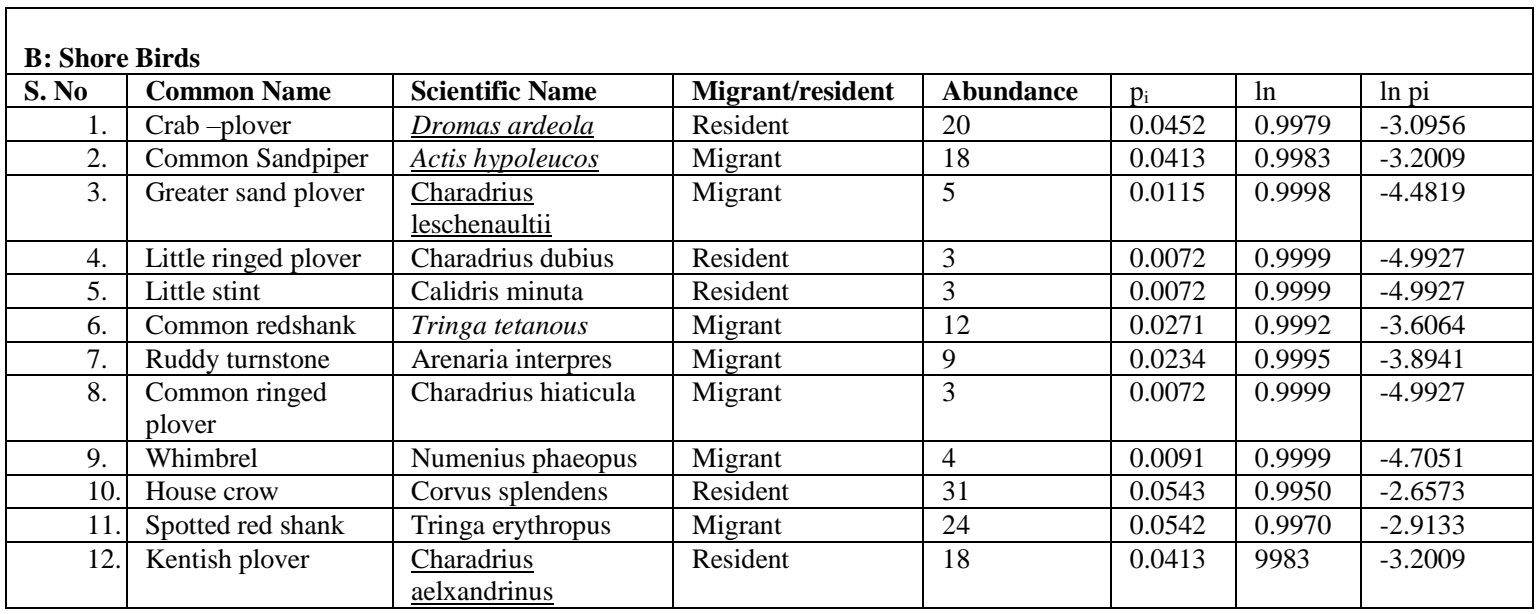

in December 142013 we under took the second survey of our study during cloudy low ppt and the sea was moving from low tide to high tide starting from 7.39 to 12.30 . the survey was uniquely marked with 232 individual shore birds (some with plumage and some were chicks) adults were marked with engraved flag and/ or color and include : 59 pink backed pelicans, 31 sooty gull, 94 sacred ibis, 72 common red shank ,64 sand piper the above mentioned species were more in number

In addition to the above shore birds and sea birds survey research we conducted frequent predator of the island and supporting plants for bird species like mangrove and some eggs of osprey and sacred ibis Third survey was conducted in February 10 starting from 3.20 to 5.45 hours in the after noon of the day during cloudy and low ppt where the weather of the island becomes comfortable to the breeding birds a number of migratory birds were found to be in the breeding season like Whimbrel

\section{Discussion And N Recommendation}

Sea birds and shore birds for their breeding chronology prefer to breed in a suitable breeding site. Absence of potential predator on this island and availability of sufficient food in the island may be the reason for the sea and shore birds chosen the site for breeding and nestling. The diversity and abundance of birds differs from place to place depending on the richness of the place, the habitat structure and the weather condition.

There were many sites in island in the coast of Eritrea, which are used as breeding sites for resident birds. Scared Ibis breed on the mangrove of Sheik said Island and Pink-backed Pelican and the Eurasian Spoonbill may also breed in the island; however detailed observations are required in the dense mangrove forest. The Crab Plover breed in many Eritrean island, they nest the sandy burrow by digging the sand. 
The highest species diversity and the abundance in Sheik Said Island can be associated with firstly, the large area that expose at low tide which is rocky, muddy and sandy is a rich source of invertebrates especially crabs. This attracts many species of plovers and waders. Secondly the dense mangrove forest is a source of juvenile fishes and invertebrates and it is a home for some species where herons, pelicans, spoonbills and scared ibis and other wader feed and roost on top of it. Thirdly, the water below the intertidal is source of fishes as food and in addition to the sandy beaches is an excellent roosting site for several waders and the sea birds, as the study observed.

During the study period the variation in diversity of the birds in each of the survey were recorded. The highest bird species richness was recorded in this area during the third survey. This might be because of favorable temperature for the birds to breed and show plumage such as pink baked pelican, crab plover, Kentish plover, sooty gulls and others as recorded in the tabular form.

There is a marked increase in species richness and abundance from the first to the third visit and many of the species which were not present in the first survey can be observed in the third survey because of summer were the beginning and it was proved that they come from Indian Ocean and still such findings must be proved over a period of time. There may be other possibilities that there were low tides of the months and hence the marine foods such as mollusks, fishes as it may be by low tides, for the birds may not be available and hence the bird species may be few in number as the data supports.

\section{Conclusion}

The island is found to be an area of ornithological important where a number of breeding sea birds come to breed and nestling. Formation of new colonies and spread into new geographical area and difficult for them because of high degree of philopatry, (Schreiber et al., 1993). So habitat modification that disturbs former colony site, introduction of avian predators and unregulated tourist visitors are the major threat to breeding birds. Therefore, implementation of regular mechanism for the above mentioned threat is current issue.

\section{Acknowledgements}

The first author expresses thanks to the Department of Biology, Eritrea Institute of Technology, Mai Nefhi, Asmara, Eritrea for providing facilities in the form of permission letters to visit the island where the research and the study site was located in the Red Sea region of Massawa, Eritrea and she was a final year student of Biology of this institute and also thanks to Mr. Russom Teklay, faculty for providing calculations of the data. The second author was her advisor and mentor for this project of this institute and this project was taken over by without any external funding source. The support given by the Massawa port officials were gratefully acknowledged for their kind cooperation and helpful throughout this research.

\section{Acronyms}

ECMIB: Eritrean Costal Marine and Island Biodiversity

GCF: Global Environment Facility

IBA: Important Bird Area

MOF: Ministry Of Fishers

\section{References}

[1]. Chriss Hillman. 2006. Handbook of during a voyage in the Red Sea. Ibis (1) 1: 337-352.

[2]. Clapham, C. S. 1964. The birds of Dahalak Archipelago, Ibis, 106: 376-388

[3]. De March, G., Chiozzi, G., Semere, D., Galeotti,P., Boncompagni,F and Fasola, M. 2006. Nesting, Overwintering and Conservation of the Crab Plover Dromas, 67: 45-47.

[4]. Emil, K. Urban and Jeffery Boswell. 1969. Bird Observation from the Dahalak Archipelago, Ethiopia, Bull Br. Orn. Cl. 89: 21-1209

[5]. Salvadori, F. B. 1954. Spedizione subsequea italiana. Note biolgiche sugli uccelli dell Isole Dahalak. Riv. Ital. Orn. 24:98-124

[6]. Schreiber and Nolan, Val. 1993, Male Parental behavior in Birds. Annual Review of Ecology and Systematics 25: 601-28le coste delle Isole Dahlak (Eritrea). Rev. Ital. Orn. 24: 75-77

[7]. Shannon, C. E. 1948. A Mathematical Theory of communication. The Bell System Technical Journal, 27: 379-423 and 623-656.

[8]. Simpson, E. H. 1949. Measurement of Diversity Index, Nature, 163: 688-689.

[9]. Smith, K. D. 1957. An annotated check-list of the birds of study. The Coralline Lisland of the Dahalak Archipelago, Red Sea. 187200

[10]. Yossief and Sammy Yohannes. 2006. Spedizione subacquea italiana. Note biologiche sugli ucceclli dell isole Dahalak. Rev. Ital.orn. 24: 98-124. 